\title{
EUROPEAN DIMENSIONS IN ROMANIAN THEOLOGICAL DISCOURSE
}

\begin{abstract}
Author:
Ioan Chirila ${ }^{1,2}$

Affiliations:

${ }^{1}$ Faculty of Orthodox Theology, Babes-Bolyai University, Romania

${ }^{2}$ Department of New Testament Studies, Faculty of Theology, University of Pretoria, South Africa
\end{abstract}

\section{Correspondence to:} Ioan Chirila

e-mail:

ioanchirila@yahoo.com

\section{Postal address:}

Str. Eremia Grigorescu 114, cod 400304, Cluj-Napoca, jud. Cluj, Romania

\section{Keywords:}

Europe; Romania;

Romanian theology;

Divine Liturgy; orthodox theology

\section{Dates:}

Received: 11 Dec. 2008 Accepted: 11 June 2009 Published: 26 Oct. 2009

How to cite this article: Chirila, I., 2009, 'European dimensions in Romanian theological discourse', HTS Teologiese Studies/ Theological Studies 65(1), Art. \#293, 5 pages. DOI: $10.4102 / 293$

\section{This article is available at:} http://www.hts.org.za

\section{Note:}

This article is a reworked version of a paper presented at the Faculty of Theology of the University of Pretoria in 2008. Prof. Dr I. Chirila is a research associate of Prof. Dr J.G. van der Watt, Professor Extraordinarius at the University of Pretoria, South Africa, and a visiting professor at the University of Pretoria.

\section{(c) 2009. The Authors.} Licensee: OpenJournals Publishing. This work is licensed under the Creative Commons Attribution License.

\section{ABSTRACT}

This article underlines particularly those aspects of Romanian theology that distinguish it from other theological reflections. By making use of liturgical discourse, Romanian theology reflects the ecumenical dimension of the prayers of the Divine Liturgy. It is this specificity that provides Romanian theology's missionary dimension within the European context. The author introduces the idea that theology is not an academic mission reserved to a group of intellectuals or to the hierarchy of the church; it is rather open to every believer - every believer is asked to be a theologian, to be a person of prayer, to speak about God while being in God. Another point of interest is the God-humanity-world relationship in an era of globalisation, with regard to which the author stresses the need for equilibrium between spiritual and scientific values and that Romanian Orthodox theology is an authentic theology of equilibrium.

\section{INTRODUCTION}

The Romanian theological discourse is one special expression of experiencing God. To be a theologian means to speak about God while existing in persona in God. These words belong to Father Dumitru Stăniloae (Stăniloae 2003), who wished to underline the profoundly liturgical and experimental character of the Romanian theological discourse, which makes it a patristic reacceptance of the apostolic kerygma. By stating that Romanian theology makes use of liturgical discourse, we are actually stating that it reflects the oikomenic dimension of the prayers of the Divine Liturgy ('For the peace of the whole world, for the good estate of the holy churches of God, and for the union of all men, let us pray to the Lord' - Fragment from the Divine Liturgy of Saint John Chrysostom) and, therefore, the personal manner of mediating participation regarding the historical, geographical and cultural environment of Europe. This participation is neither regarded as a scientific contribution nor appreciated in its true value.

Undoubtedly, European culture has a Christian origin, but in the course of time it has undergone deep changes, having become secularised against its own Christian background. The great change occurred in the modem epoch. Under the influence of the Enlightenment (18th century), European culture declined the deductive method whose centre of gravity was divine revelation and oriented itself towards the inductive method stemming from natural revelation or, more precisely, from the concrete reality of the world we live in. Therefore, a substantial mutation occurred in the field of knowledge as one passed from supranatural knowledge, which had its origin in God, to natural knowledge, which is completely dependent on humanity.

The paradox of Enlightenment culture consists of the fact that humanity's political freedom and democracy have been accompanied by the loss of inner freedom. As long as this side of freedom is ignored in order to stress only political freedom as a characteristic feature of democracy, people will not be able to find their own inner equilibrium. Thus, we have reached a point where we cannot move forward in the analysis of this issue unless we discover the spiritual cause at the origin of the above paradox. This cause was emphasised by the Assembly of the World Council of Churches in Canberra, Australia, at the beginning of 1991. On that occasion it was shown that the real cause of deism and anthropocentrism, which represent the two major dimensions of the secularisation process, comes from a theology that created confusion between the transcendence of God and his absence from creation. In order to understand the deeper spiritual significance of these phenomena, let us analyse each of them.

Deism is the result of a philosophical and theological conception that states that after creating the world, God isolated himself in an inaccessible transcendence. (The founder of deism is the 1st Baron Herbert of Cherbury (see Todoran and Zăgrean 1991:201). A well- known theologian, Yves Congar (1904-1995), said that 'one of the greatest misfortunes which affected contemporary Christianity consisted in the fact that the Trinity was isolated both from the people and from the cosmos in transcendence' (Congar 1966:17). If the Christian doctrine on the Trinity implies, on one hand, a divine nature and three Persons, in order to explain the assertions of the theologian cited, a logical priority must be given to the divine nature over the three Persons. Thus, through the divine nature that remains incommunicable, the expression of the Christian God in the Trinity has been completely isolated in transcendence both from the people and from the cosmos in transcendence. Another well-known theologian, Karl Rahner (19041984), showed that

the separation between nature and person occurred in the scholastics due to some causes not yet very clear. Here one no longer deals with God-the-Father as an unborn principle both in Divinity and in the reality of the world, but first of all with the divine nature common to all the three Persons. Therefore, the Trinity has been closed in a deep isolation, which risks being considered to have no interest for religious existence.

(Rahner 1967:115)

The ideas expressed in the above-mentioned text are very important for understanding the issue with which we are concerned. If God in the Trinity is no longer seen as having a personal reality but as possessing an impersonal nature, the relationship between God and humanity ceases to be a relationship of personal love and becomes a simple formal abstract knowledge of God, which diminishes the interest of the faithful in divinity and causes the human being to focus on him- or herself. 
This drama of contemporary humanity was best understood in Christianity by Orthodoxy in particular. We remark a possible answer to this spiritual crisis in the Orthodox position formulated by Father Stăniloae (2002) when writing about the Holy Trinity, as well as by Father Dumitru Popescu when speaking about the teonomic and autonomic character of creation (Popescu 1993). These few elements are the expression of a Romanian contribution to the European theological discourse, while the comparative presentation (by comparison with Congar and Rahner) illuminates a European dimension of the Romanian theological discourse. But presenting the specificity of Orthodoxy is not what I intent to do. My wish is to present one real contribution of the Transylvanian Romanian Christianity.

Between the 16th and 19th centuries, the structures of Romanian theological education were organised in concordance with European universities. For example, the director of the first Romanian Orthodox Theological Academy from Sibiu, Gheorghe Lazăr, adopted European books for exegetical studies. Biblical exegesis and archaeology courses were written by following the example of German teaching in Iena Theological Institute. A new perspective emerged in the 20th century. At this time, the participants in the Ecumenical Council of the Churches from Transylvania began to appreciate the importance of patristic literature for the correct understanding of Oriental dogmatic theology. I wish to introduce here some representative names: Nicolae Bălan ${ }^{1}$, Nicolae Colan², Nicolae Mladin ${ }^{3}$, Nicolae Corneanu ${ }^{4}$, Dumitru Stăniloae ${ }^{5}$, and Antonie Plămădeală ${ }^{6}$. Due to their participation, new themes were accepted for ecumenical debates, themes such as the characteristics of Orthodoxy or the Person and work of the Holy Spirit. Through the approval of these new themes, an interesting statement was made: Return to the Holy Fathers. I am not saying that during the era of communism the Romanian theological discourse had a European dimension. However, I believe that the general presentation of the Orthodox faith realised by Father Stăniloae, as well as the principles of the Orthodox Romanian participation in the ecumenical debates realised by Father Ioan Bria was a real contribution to European cultural understanding. The latter proves particularly important for future European Christian perspectives.

It is a fact that Orthodoxy is identical in its faith content and worship with the faith content and worship of primitive Christianity. Yet the extraordinary and absolutely genuine fact about it is that while being essentially the continuation of the faith, worship and spirituality of the undivided church of the first centuries, Orthodoxy meets in a perfect manner the spiritual need of the people who have remained loyal to it up to this day.

1 Nicola Bă (1882-1955), Metropolite of Ardeal (1920-1955), honorfic member the Romanian Academy (from 1920). Works: Paul, apostle of Jesus Christ (1931) Religious scepticism (1912), Fighting church (1910), The ecclesiastic problem in Romania and the autonomy of our church (1910), Save, O, Lord, thy people (1945) and Church and life (1947).

2. Nicolae Colan (1893-1967), Rector of the Theological Academy in Sibiu (19281936), Bishop of Cluj (1936-1957), member of the Romanian Academy (from 1942), Metropolite of Ardeal (1957-1967). Works: Saint Paul to Philemon: Christianity and slavery (1924), The Bible and the intellectuals (1929), A chapter of missionary slavery (1924), The Bible and the in
strategy (1926) and Medallions (1940).

3.Nicolae Mladin (1914-1986), Metropolite of Ardeal (1967-1981). Works: Living for me is the Christ (1941), The church of God in the light of the Holy Scriptures (1942), Light from light (1947) and When brothers are together (1956).

4.Nicolae Corneanu (n. 1923), Bishop of Arad (1960-1962), Metropolite of Banat (from 1962). Works: Aspects of ancient Christian literature (1984), Patristica mirabilia (1987), Teachings of the Orthodox Church (1987) and Quo vadis? (1990).

5.Dumitru Stăniloae (1903-1993), dogmatist. Dogmatic theology professor in Sibiu (1929-1946) and Bucharest (1947-1958; 1963-1973), Rector of the Theological Academy in Sibiu (1936-1946), member of the Romanian Academy (from 1992). Works: Orthodox Dogmatic Theology, 3 vol. (1978), Jesus Christ or the Restoration of Man (1943), The Life and Teaching of St Gregory Palamas (1938), Spirituality and Communion in the Orthodox Liturgy (1986), Studies of Orthodox Dogmatic Theology (1990) and Jesus Christ the Light of the World (1993).

6.Antonie Plămădeala (1926-2006), Rector of the Theological Institute in Bucharest (1971-1974), Metropolite of Ardeal (1982-2005). Works: That they may all be one (1979), The serving church (1986), Tradition and freedom in Romanian spirituality (1983), Vocation and mission in our times (1984) and New meanings to old texts (1983),
(1999).
Orthodoxy has not changed essentially over 2000 years. It is due to this fact that Orthodoxy did not become impregnated during these centuries with anything that would require elimination in our times. Nor did Orthodoxy make an essential feature of its existence out of the temporary element of one historical period or another, needing to dispose of it nowadays. Orthodoxy did not turn 'middle-aged', as happened with Roman Catholicism; nor is it the by-product of the protest movement of the Renaissance as is the case with Protestantism. It does not seek, even today, to reform itself essentially in order to accommodate itself to our times by way of secularisation.

Orthodoxy has not introduced into the mysterious sanctuary, long-proven by a simple expression of faith, subtle and complicated innovations of certain maitres, dominated by the desire for a certain sweetness offered by an intellectual exercise rather than by the abysmal and overwhelming awe of the mystery of the relationship between humanity and God. These realities are well expressed in the works of Father Stăniloae $(1986 ; 1987)$

Orthodoxy has never mixed superfluous patterns of human thought with the simple, mysterious, majestic, permanently and inevitably lived essence of the fundamental data of the mystery of salvation. As a natural consequence, Romanian theology has largely debated the problematic of the holy mysteries from an Orthodox perspective as well as from an interconfessional one.

Regarding the social dimension, Orthodoxy has preserved a mass character, for the people in their simplicity remain largely unsensitive to the successive ideologies of the historical periods but stay open to the real and essential problems of all times. The volumes issued by the Patriarch Iustinian (1949) are representative of this aspect. But when we speak about a social mission of the church, it is useful to go back in time, to the communist epoch. For a long time, severe restrictions were imposed on the church. In this context, accomplishing a social mission was extremely difficult. Priests had become faithful custodians of a tradition, representatives of a national institution that played an important role in the past; they were spiritual parents conveying the popular pious experience. Thus, the priests could not exercise their critical spirit upon the evolution of society and state control of religious life. The communist regime cultivated the illusion that there could be no better society and that atheism was not so noxious after all. After a period during which the aim, both at the ideological and the political levels, was desacralisation of Christian values, a social apostolate is not an easy task. Because of communist ideology, people became afraid of history, wanted to abandon the global ideological systems that were aggressing them, wished to retire into religiosity as an esoteric space, somehow irrational with revelations and mysterious apparitions. That is why in our times, despite positive statistics, there is no record of genuine participation by citizens in church services. The vestiges of atheism are there, visible and invisible.

It is crucial to specify that secularisation of Orthodoxy cannot be a solution to the contemporary spiritual crisis. On the contrary, Orthodoxy knows well that by becoming secularised it would lose sight of humanity and would no longer respond to the fundamental problems of salvation that keep burning under the ashes in the very depths of humanity's being. However, Orthodoxy has always accommodated itself to the times. It has always helped the loyal faithful in all their circumstances and in their endeavours and struggles to preserve their existence, to free themselves from alien domination.

An aspect of this accommodation is the fact that the Romanian Orthodox Church, having introduced the national language (vernacular) in church services over three centuries ago, helped to create a Romanian literary language. Particularly important in this field are the works of Metropolite Antonie Plămădeală (1983, 1984a, 1984b). But this accommodation of Orthodoxy 
of itself to the times did not mean an alteration of its being a mystery, nor did it mean a replacement of the mystery by an ideology determined by one epoch or another. Orthodoxy has done all this by fully understanding the value of creation. It has always remained the mystery of simple data but fundamental and necessary for the religious life. Orthodoxy has always done and still does things that way. In this respect it mediates Christ to the faithful, Christ who is the same yesterday and today and for ever' (Heb 13:8). It is Jesus Christ who, being the same forever, answers in as perfect a manner today as he did yesterday. While human ideologies are rather unstable, for each one dies and another takes its place like the priests who were many in number' (Heb 7:23),

He holds His priesthood permanently, because He continues for ever. Consequently He is able for all time to save those who draw near to God..., since He always lives to make intercession for them.

(Heb 7:24-25)

Orthodoxy has always understood that it needs no changing for proclaiming the perfect dignity of the High Priesthood of Christ, nor does it need to add or suppress anything, but rather that its only task is to emphasise time and again this dignity in its fullness. The saying: 'Ecclesia semper reformanda' does not apply in Orthodoxy since Orthodoxy communicates Christ integrally, he who is 'semper conformis cum omni tempore' (Staniloae 1987:129).

The mystery of salvation has always been lived to the full within Orthodoxy. The few recent terms adopted by the ecumenical councils did not mean to bring down the mystery to a rationalistic definition but intended precisely to guarantee its being a mystery as against those temptations to rationalise and limit it or to make it disappear altogether. The ecumenical councils protected the mystery of our salvation, according to which the infinite source of life was made accessible to us to the extent that the human person became accessible to us as our neighbour. The councils drew a line between the pantheistic Hellenism under the guise of gnosis and God as Person in communion and thereby have confirmed the eternal value of the human being as person. The councils withstood the rationalist temptation to void the mystery of salvation of meaning and thereby to make salvation illusory by turning God into an essence (ousia), submitted to rational laws, by foreseeing the disappearance of humanity in that essence.

A current objection to Orthodoxy is that it accommodated itself to medieval Renaissance and also Byzantine mentality and buried the living kernel of the Christian mystery under a heap of formalist and aristocratic splendour that no longer corresponds to our time. We do not deny that Orthodoxy experienced a Byzantine influence. But this influence did not touch upon the essence of the Christian mystery. What has been considered to be a Byzantine heritage in the life of the Eastern Orthodox Church is, particularly, the multitude of symbols expressing both the Christian faith and its being as lived in worship, in art and in life. But the Byzantine impact and influence could only foster the development of a symbolism inherent in the expression of the Christian mystery.

The intellectual definitions and the doctrinal expositions whereby the West has tried (and still tries) to replace the exposition of mystery by way of symbols have their origin in the conviction that this mystery can be expressed exactly in human words. In reality this mystery is narrowed down or even diluted whenever one wishes to encapsulate it in the strict meaning of words and intellectual definitions. The paradoxical and apophatic fullness of the mystery of salvation is more exactly rendered by symbols. To speak of the Cross and Resurrection in a general way, to contemplate them in icons, to express them in symbolic and liturgical gestures suggests in a more realistic and existential way the mystery of salvation than does the satisfaction theory of Anselm or the penal theory of the Protestants who are able to express but one aspect of the incomprehensible mystery of salvation. Therefore, if Orthodoxy needs to accommodate itself to the needs of contemporary humanity, this cannot consist in a total reduction of the symbolic expression. It can only consist in a simplification of this expression in order to see straight away the great symbols of the Christian mystery that correspond to the great, simple, permanent evidences and spiritual necessities of humanity, namely God near to us as a human person; Resurrection through the Cross; glory through humility; power to restrain oneself and patience; freedom through grace; the value of this life through faith in the hereafter; individuality through communion; development of one's own personality through self- denial; and so on.

Certain characteristics of Romanian Orthodoxy express precisely the comprehension of the mystery of salvation in the light of Orthodox Tradition..$^{7}$ They might help the completion of Christian testimony in Europe. These religious behaviours and traits define both the common people and hierarchs in the Romanian territories. We have never initiated confessional wars, nor have we killed in the name of the Bible. The Romanian Church never condemned its own faithful for being heretical, nor has it intervened in the dogmatic disputes of other confessions, always remaining solidly anchored in the tradition. On the contrary, the Romanian Church has always paid particular attention to spirituality, seeing its faithful to salvation and having an ecumenical attitude towards other confessions, denominations and religions. Neither the present situation of the Romanian Orthodox Church nor its future development projections can be analysed and evaluated objectively without taking these features into consideration.

\section{THE MISSIONARY DIMENSION OF ROMANIAN THEOLOGICAL DISCOURSE IN A EUROPEAN CONTEXT}

Let us consider the missionary dimension of the Romanian theological discourse in a European context.

Communist ideology has destroyed the fundamental markers of Christian society. Many people cultivated the illusion that once the political regime changed, it would be natural to return to a religious society. Others, noting the degree of economic, moral and cultural poverty, believed that religion itself had lost its power and influence so that in the present situation religion cannot be but palliative. While it is true that the Orthodox Church can intervene actively in education, the charity field or people's welfare, the existence of these possibilities does not automatically ensure real fructification of them. In this situation, the Romanian Orthodox Church facing the present transformed society has an important mission to fulfil in order to answer to the social and spiritual needs of its faithful. The first and main modality is the path of the Gospel, that is of radical conversion to a transformation of human existence and community following the Gospel principles. Only in this context, through a sanctification of humanity and a real metamorphosis of society, can the healing virtues of the Orthodox faith and spirituality be found. Therefore, the Romanian theological discourse has a missionary dimension, as it is not only capable of spiritually guiding our society but also of restoring the European religious experience. On the other hand, theology is not an academic mission reserved to a group of intellectuals or to the hierarchy of the Church but is open to every believer. Every believer is asked to be a theologian, to be a man or woman of prayer, or, as stated earlier in this article, to speak about God while existing in God.

Thus, the pastoral mission among the poor and discouraged, among those confused, among young people as future creators of our history is not a responsibility reserved to the church as an institution but is open to every Christian. Any suffering person must find within the Christian community genuine therapy, a communion of support and help. The problems of the Christian community and of the Christian family in particular are a main

7.(The expression belongs to M. Dumitrana, The mission of the Romanian Orthodox Church today, www.crvp.org/book/SeriesO4/IVA-24/chapter_xii.htm). 
concern of the Romanian theological discourse, which identifies itself with the patristic perspective on family. Therefore, from a missionary point of view, the major interest is the uninterrupted apostolic tradition, the only tradition that differentiates the church belonging to Christ from other religious movements. This tradition is embodied in the life of the local martyrs and saints, in the local cult, culture and history of the believers who constituted a particular church. The Orthodox Church doubts the truth of any mission that does not accept the historical, chronological transmission of the faith in Jesus Christ and the Gospel's embodiment in the spiritual experience of a concrete people, existing in a certain place and time. The church cannot withdraw from the responsibility to evangelise, to preach the Good News to the present generation. This mission is part of the essential and permanent calling of the church. In this context, Romanian Orthodoxy must select ecumenical themes and activities worthy of further exploration. There is reciprocity between the mission of the local church and the ecumenical unity of all churches, between the specific identity of a church and the identical universality of Christ in each of the churches and at the same time in all of them. In this context, the Romanian Orthodox Church has to develop continuously the relationship with other churches and Christian communities in Romania. Proselytism is especially practised in non-ecumenical situations, when the churches do not mutually recognise or know each other. Particularly representative in this field is the work of Metropolite Nicolae Corneanu (2001), when speaking about the role of the Romanian Orthodox Church in the European integration in the context of a secularised society.

In an era dominated by the process of secularisation, ecumenical dialogue must be founded on a profound theological reflection. Given the situation, we consider that the Romanian theological discourse covers the most acute problems of contemporary humanity. This clear formulation of the Romanian Orthodox position, solidly anchored in the tradition as keeper of the revelation, proves indispensable in the process of restoring the spiritual life of contemporary Europe.

\section{THE RELATIONSHIP GOD - HUMANITY - WORLD IN AN ERA OF GLOBALISATION}

Human existence relies on a basic triangle: God, humanity and the world. The main point consists of the fact that it is not the relation of humanity with nature or itself that can reveal the ultimate mystery of its existence but only its relation with God. A real culture must surpass the deism of contemporary culture, affirming at the same time both God's transcendence of creation and God's presence in creation. Maxim the Confessor tells us that the Holy Spirit is not absent from any being and especially from those worthy of receiving reason. It supports them all in their existence, as though its providential power, God, is present in all of them. The Spirit activates natural reason in everybody; it enables the one who is willing to receive the right thoughts about nature to feel aware of the wrongs committed against nature. We happen to find many people from various nations who live a life of good deeds and reject the unjust laws that once used to rule them.

Therefore, we can generally say that the Holy Spirit is present in everybody. Here we are in a universe quite different from a world that exists and functions through itself. This universe is a dependent world that maintains a dynamic relation with God. God is the one who permanently supports the existence of the world and leads it to the accomplishment of the purpose for which it was built, that is the new heaven and earth of the Kingdom of God in Christ. The presence of God in creation is very important for a democratic society as it proves that the purpose of Christianity is neither to sacralise or to dominate the world in the name of Christ nor to turn it into an object of irrational exploitation, as we have seen above. Its purpose is to transfigure humanity and creation in Christ, as well as the church, through the work of the Holy Spirit. This process of transfiguration of humanity and creation is possible both from a scientific point of view, as science shows us that matter is a concentration of spirit and energy, and from a theological point of view, as Scripture tells us that the face of Christ on Mount Tabor was shining like the sun and his clothes were dazzling white (Mt 17:20).

The transfiguration process has two aspects. First of all it is an exterior process, achieved through science and technology. In this process, achieved according to the will of the Creator, technology represents the bridge between the shapes of the spirit and the structure of nature, namely a transfiguration of nature. Just as the artistic genius introduces a part of the spiritual world into the material world, so the technical genius imposes on nature expressions and requirements of the spirit. That is so much more possible today when science has come to the conclusion that the world of the macrocosm is so complex that it can no longer be explained through natural laws. It is not surprising then if scholars assert that science is knocking at the door of transcendence. We learn from the Holy Scripture that technics appeared in the world after the fall of humanity into sin. In its earlier state humanity had no need for technics as humans possessed a special spiritual power that enabled them to act directly upon nature. In fact, even Christ, who reestablished humanity in its early state, healed diseases, brought the dead back to life and calmed the enraged forces of nature without using technics but only by his spiritual power. One of the Fathers of the Church, John Chrysostom, says that 'as the first man created had no needs of any kind, he was not obliged to use craftsmanship and techniques to satisfy his needs' (Chrysostom 1987:125). After humanity's fall into sin, the world was made a better place as techniques progressively developed. Technique plays an extremely positive role, as it enables humanity to contribute to the transfiguration of creation.

Contemporary humanity has lost so much of its spiritual power that it abuses techniques when dealing with nature. The massive pollution of nature, which has reached a planetary level, is the result of this irrational usage of techniques. But transfiguration concerns not only the exterior nature of humanity through technology but also its inner nature through the Holy Spirit. Due to the power of the Spirit that embraces both body and soul, according to the Apostle Paul, 'Man's body is the temple of the Spirit' (1 Cor 6:19). A real revolution is produced within the human being, designed to turn passions into virtues, through a theandric work of the Holy Spirit and faithful humanity. This is because the purpose of Christianity is not to do away with the passionate side of humanity but to move it from evil to good, giving humanity real inner freedom. Humans can never be rid of their passions or obtain real inner freedom and openness towards their fellows all by themselves. Only the power of God presents the fulcrum that enables humans to be free and true masters of creation. The transfiguration of the human being in Christ has outstanding importance for democracy. As long as humans remain prisoners of irrational forces in their inner life that they cannot control, democracy becomes an opportunity for the manifestation of aggressive forces that deeply affect social life. The outbursts of aggression, violence and hate that we meet everywhere in the world are telling proof of this point of view. The more inner freedom humans obtain through the power of divine uncreated energies, the more they become the promoters of spiritual values and of the strengthening of democracy as well. Real democracy is based both on the external and the internal freedom of humanity. Only in these terms can one fill the great gap between the rapid scientific progress of the contemporary world and its slow spiritual progress.

True democracy must rely on equilibrium between spiritual and scientific values, as only the spiritual power of humanity will allow it to put technics in the service of life and common welfare. As we tried to show in this essay, contemporary humanity can choose between an independent conception of the world and a dependent one. In this context, Romanian liturgical expression may be a vital contribution to the restoration and revitalisation of European spirituality. 


\section{CONCLUSION}

The European culture was and continues to be a consistently Christian culture. The Romanian culture of Transylvania must be situated in this Christian European context and be recognised as an integral part of the history of Romanian churches in Transylvania between the 12th and 19th centuries. We cannot speak about a veritable recognition of their spiritual and national identity; therefore, a Romanian theological contribution to the European cultural treasure was practically impossible at the time. The Romanian theological schools of Transylvania made their debut in the 18th century (1753-1786), with schools at Sibiu and Blaj.

I would point out two presentation perspectives of Romanian theology. There is a primary phase that I would call the participation stage that includes structural, curricular and methodological impropriations. The research of existing bibliographies shows us that the course support was influenced by two primary sources: Russian theological literature and German sources (especially S. Barbara Institute and Iena Theological Institute). Then there is a secondary phase, of the greatest amplitude, that occurred at the end of the 19th century and that was determined by the extensive organisation of the Romanian theological academic system. I wish to mention here several academies: Preparandia of Arad, Oradea Academy, Sibiu Academy, Blaj Academy, Cluj Academy, as well as a rich structure of confessional high schools.

A question inevitably arises: Can we speak about a real contribution of these theological institutions to European culture? I would answer starting with the scientific project of Cluj Academy, where several studies that transcended the area of confessional limitations were elaborated, for example G. Stănescu - Islamul [Islam]; Liviu Galaction Munteanu Studiul Vechiului Testament [Old Testament studies], Studiul Noului Testament [New Testament studies], Vechiul Testament şi creştinismul [The Old Testament and Christianity] and Enciclopedia Creştinismului [The encyclopaedia of Christianity], and I. Bunea - Psihologia rugăciunii [The psychology of prayer] and Fenomenologia conştiinţei morale [The phenomenology of moral conscience], projects that were destined to maintain communities in an evangelic state.

I would also mention here some of the projects realised in partnership with other European universities for the composition of several volumes: The characteristics of European theological discourse; Transylvania - presentations were realised from an Orthodox, Greek Catholic, Roman Catholic and Protestant perspective; Munich - The reception and interpretation of the Bible in European churches; Lausanne - The statute of religion in Europe. I hope that the elements from the quoted bibliographical sources shown here will offer the possibility of creating an objective perspective on the involvement of Romanian Orthodoxy in the Christian European context.

\section{REFERENCES}

Bria, I., 1995, Ortodoxia în Europa: Locul spiritualității române [Orthodoxy in Europe: The place of Romanian spirituality], Editura Mitropoliei Moldovei şi Bucovinei, Iaşi.

Bunea, I., 1992, Aspecte ale spiritualităţii ortodoxe [Aspects of Orthodox spirituality], in D. Stăniloae (eds.), The Romanian Spirituality, pp. 280 - 291, EIBMBOR, Bucureşti.

Chrysostomus, J., 1987, Omilii la Facere [Homilies on Genesis], EIBMBOR, Bucharest.

Congar, Y., 1966, 'Le Christ dans l'économie salutaire et dans nos traités dogmatiques', Concilium 11, 11-26.

Corneanu, M.N., 2001, Credinţă şi viaţă [Faith and life], Dacia, Cluj-Napoca.

Delumeau, J., 1993, Religiile lumii [World religions], Humanitas, București.

Dumitrana, M., 2008, The mission of the Romanian Orthodox Church today, viewed 11 September 2008, from www.crvp. org/booklSerieso4/IVA-24/chapter xii.htm.
Evdokimov, P., 2003, Vârstele vieții spirituale [The ages of spiritual life], Christiana, Bucureşti.

Iustinian, P., 1949, Apostolatul social [Social apostolate], EIBMBOR, Bucureşti.

Newbigin, L., 1983, The other side of 1984, WCC, Geneva.

Newbigin, L., 1988, Foolishness to the Greeks, WCC, Geneva.

Păcurariu, M., 1986, Istoria Bisericii Ortodoxe Române [The history of the Romanian Orthodox Church], EIBMBOR, Bucureşti.

Palama, G., 2005, Filocalia Românească, vol. VII, Humanitas, Bucureşti.

Plămădeală, A., 1983, Tradiţie şi libertate în spiritualitatea ortodoxă [Tradition and freedom in the Orthodox spirituality], University of Sibiu, Sibiu.

Plămădeală, A., 1984a, Pagini dintr-o arhivă inedită [Pages from an innovative archive], Humanitas, Bucureşti.

Plămădeală, A., 1984b, Biserica slujitoare [The serving church], Humanitas, Bucureşti.

Popescu, D., 1993, Teologie şi cultură [Theology and culture], EIBMBOR, Bucureşti.

Popescu, D., 1996, Ortodoxie şi contemporaneitate [Orthodoxy and the present times], Diogene, Bucureşti.

Rahner, K., 1967, Quelques rémarques sur le traité dogmatique: De Trinitate, ecrits théologiques [A few remarks on the dogmatic treaty: The Trinity, theological writings], vol. VIII, Desclée de Brouwer, Paris.

Savin, I., 1992, Creştinismul in trecutul nostru istoric [Christianity in our past], EIBMBOR, București.

Stăniloae, D., 1986, Spiritualitate şi comuniune în liturghia ortodoxă [Spirituality and communion in the Orthodox liturgy], Universitaria Publishing House, Craiova.

Stăniloae, D., 1987, Chipul nemuritor al lui Dumnezeu [The immortal image of God], Universitaria Publishing House, Craiova.

Stăniloae, D., 1994, Some characteristic features of Orthodoxy: From the hommage to Nicos A. Nissiotis, Aohnai, Athens.

Stăniloae, D., 2003, Teologia dogmatică Ortodoxă [Orthodox dogmatic theology], EIBMBOR, Bucureşti.

Stăniloae, D., 2004, Spiritualitate şi comuniune in liturghia ortodoxă [Spirituality and communion in Orthodox liturgy], EIBMBOR, Bucureşti.

Todoran, I. \& Zăgrean, I., 1991, Teologia dogmatică pentru seminariile teologice [Dogmatic theology for theological seminaries], EIBMBOR, București. 